\title{
大容量で高効率なダイナミック光パスネットワークに向けた要素技術
}

\author{
並木 周 \\ 産業技術総合研究所ネットワークフォトニクス研究センター（３05-8568 茨城県つくば市梅園1-1-1 中央第2）

\section{Enabling Photonic Technologies for the Extremely Energy-Efficient High-Capacity Dynamic Optical Path Network}

\author{
Shu NAMIKI \\ National Institute of Advanced Industrial Science and Technology (AIST), Network Photonics Research Center \\ 1-1-1 Umezono, Central 2, Tsukuba, Ibaraki 305-8568
}

(Received February 13, 2012)

\begin{abstract}
This article will review dynamic optical path network (DOPN), recently proposed by AIST, that is a promising technology to dramatically reduce the energy consumption allowing the sustainable growth of the network traffic in the forthcoming ultra-high definition video era. Then, some of the enabling photonic technologies being developed at AIST will be introduced: they are intersubband quantum well waveguide devices; silicon photonics optical switches; and all-optical signal processing through highly nonlinear fiber.
\end{abstract}

Key Words: Optical network, Green ICT, Optical signal processing, Parametric processes, Optical path network

\section{1. 増大するネットワークトラフィックと 行き詰まる既存技術}

インターネットトラフィックは，現在も年率30 40\% の割合で増加し続けている。 スマートフォンやタブレッ 卜型PCの普及などにより, 将来もこの傾向は続くもの と考えられる。 トラフィックの成長は新しいアプリケー ションひいてはイノベーションを引き起こし, それが社 会経済の発展に大きく貢献している.

年率1.4倍のトラフィック増をたとえば20年間支え続 けることは，その間に1000倍程度の大容量化を行うこと を意味しており, 容易ではない. 光通信技術だけ見ても これまでの20年間は, Erbium doped fiber amplifier(EDFA) の実用化, wavelength division multiplexing (WDM) 伝送技 術の普及, ラマン増幅技術や誤り訂正符号の導入, 最近 では位相変調など高度な変調方式によるスペクトル効率 の向上など，多くの革新的技術が生み出されてきた。そ して，ついに学会では光ファイバ伝送の原理限界といわ れる非線形シャノン限界 ${ }^{1)}$ であファイバ1芯あたり $100 \mathrm{Tbit} / \mathrm{s}$ 伝送が達成された2).

この様に, 光ファイバ1芯の伝送容量を将来に向けて 桁違いに改善することはもはや望めなくなってきてい る. 一方, ネットワークのもう1つの重要な構成要素で ある, 電子デバイスやIPルータの性能の進展を見ても同 様に将来に向けて桁違いの特性改善が望めなくなりつつ
ある。まず，現在のハイエンドIPルータのスループット はシングルシェルフで数Tbit/s程度にすぎず, 光ファイ バの伝送容量に遥かに及ばない。さらにスループットを 増大する阻害要因として近年注目されているのが，ネッ トワーク全体の消費電力である3).

Fig. 1に, 日本のトラフィックと対応する国内のIP ルータ全体の電力消費量を示す。この図から明らかなよ うに，IPルータはそもそも消費電力がスループットに大 きく依存する，その比例係数は多少の改善傾向はある

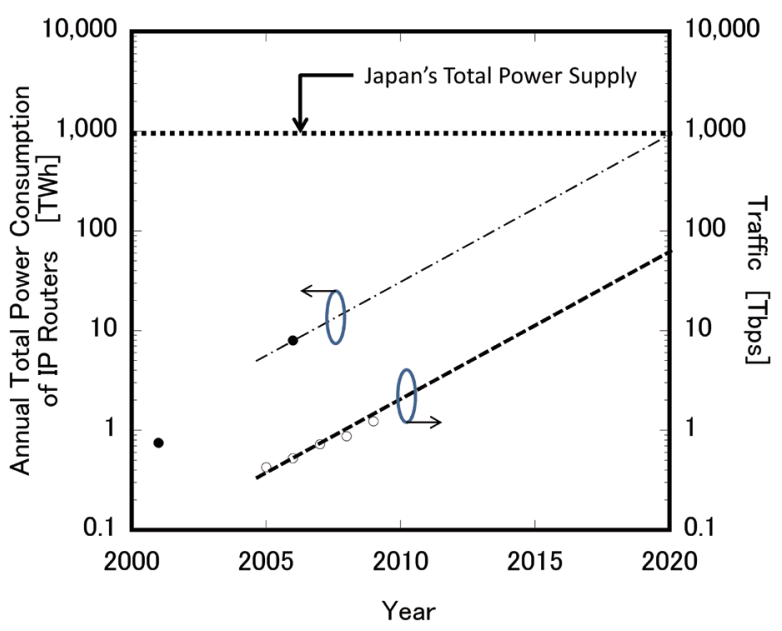

Fig. 1 Transition of the total power consumption of IP routers and traffic. 
が，概ね数 $\mathrm{nJ} / \mathrm{bit}(\mathrm{W} / \mathrm{Gbps})$ である ${ }^{4)}$ 。その結果，トラ フィックが数桁増大するためには，電子デバイス技術の 改善を考慮しても，いずれはIPルータ全体の消費電力も 数桁増大せざるを得ない. ところが, 国全体の電力供給 量も限られており, トラフィックの増加可能な量も限ら れることになる。

このように，ネットワーク・トラフィックは現状の延 長ではスケールしないことが懸念される。その大きな要 因は，上述のとおりネットワーク機器の消費電力がトラ フィック量に強く依存するためである。 そこで, この依 存性を断ち切る新しい技術が望まれる。それが，光によ る抜本的な解決である. 光スイッチは, 基本的に光の伝 搬経路を空間的に切り替えるものであり，そこを通る信 号の帯域にはほとんど依存しない。すなわち，光スイッ チの消費電力はスループットには依存せずに, 扱う光パ スの数に依存する。 その依存性は, 光スイッチそのもの を駆動する消費電力というよりもむしろ, 光スイッチの ポートに設置する光増幅器の消費電力によって決まり, 比例係数は, 〜 $1 \mathrm{~W} /$ portである. このように, 光スイッ チの, IPルータとは異なるエネルギースケーリングに着 目した省エネな新しいネットワークの実現が強く望まれる。

\section{2. 光スイッチを駆使する ダイナミック光パスネットワーク}

光スイッチはそれ自体では, どの入力ポートをどの出 力ポートに切り替えればよいかという情報を持ち合わせ ないので, 光スイッチによって構成される光ネットワー クとは別に，これを制御する制御プレーンとなるネット ワークを併設して，多数のユーザからのリクエストに応 える資源管理技術が不可欠となる。こうした新しく目指 すべきネットワークを，我々はダイナミック光パスネッ トワーク (dynamic optical path network: DOPN) と呼び, そのための垂直連携型要素技術開発を推進している5

概してダイナミック光パスネットワークは, ユーザの リクエストによって切り替わる光回線交換網であり, 転 送するデータ量が巨大だがばらつきが小さく, 事前予約 によるサービスに適し, 安定かつ保証された回線帯域が 重要となる，映像中心のサービスを提供することに適し ている ${ }^{3)}$. 事実, 増大するトラフィックのほとんどが映 像コンテンツの転送であることが報告されており†，ダ イナミック光パスネットワークはまさに増大する巨大ト ラフィックを収容し映像系サービスを提供するのに最適 なネットワーク形態となりえる.

では，実際に光スイッチを駆使して全国規模の光パス ネットワークを構成した場合, どの程度の省エネが期待 できるのか，この問いに応えるために，我々は，ごく簡 単なトポロジーを想定し大まかにネットワーク全体のト ラフィックあたりの消費電力を試算した。そその結果, 現 在のインターネットに比べて数桁の効率改善が見出され

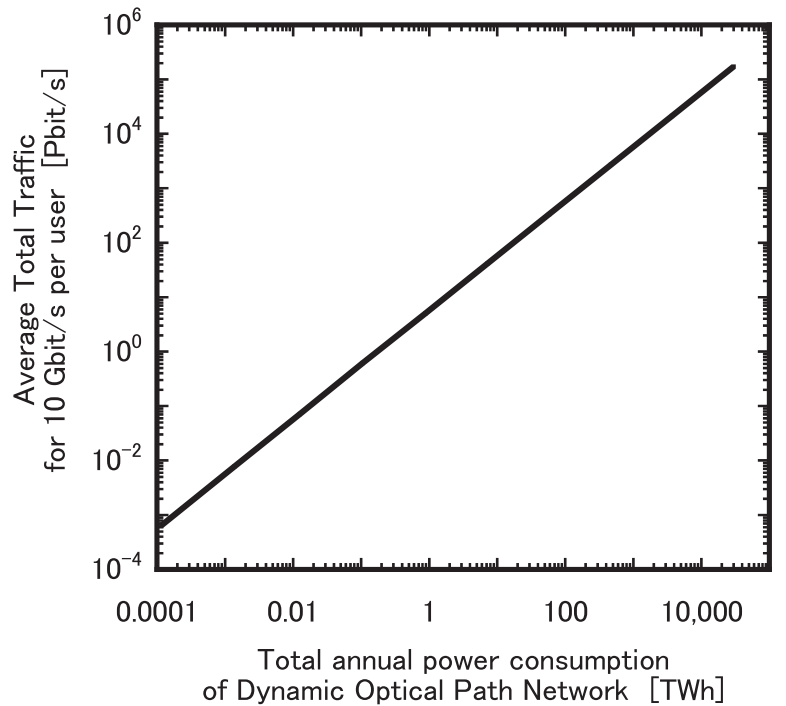

Fig. 2 Power efficiency of DOPN.

た 。 Fig. 2にその結果のみを示す。横軸は，ユーザあた りの平均伝送レートを $10 \mathrm{Gbit} / \mathrm{s}$ したまま，ユーザ数を 変化した際のネットワーク全体の総トラフィックであ る。現在のインターネットは，総トラフィックがおよそ $1 \mathrm{Tbit} / \mathrm{s}$ で，ルータの総消費電力が年間 $1 \mathrm{TWh}$ なので, 卜 ラフィックあたりの効率を比較すると5桁近い改善が見 达まれる。

実際にダイナミック光パスネットワークを現実のもの とするためには，波長やファイバ単位などの階層型ルー ティング6)を導入して，さらにネットワークの効率化を 図る必要があるだけでなく，以下に言及するようにさま ざまな光通信技術を見直し新たに開発していく必要があ る.

\section{3. ダイナミック光パスネットワークを} 実現する要素技術

ダイナミック光パスネットワークは, Fig. 3にその概 念図を示すように，従来のIPネットワークと併設され， 得意な映像を中心とした巨大情報のやり取りに用いられ ることを想定している77. 従って，ダイナミック光パス ネットワークのユーザには，光スイッチを介して，巨大 な映像情報をやり取りするための光パスが提供されるこ とになる。

ダイナミック光パスネットワークに用いられる光通信 技術は，次の3つに分類される:(1) 光パス・インタ フェース (光トランシーバ技術), (2) 光パス・プロセッ サ(各種光スイッチ技術), (3) 光パスコンディショニン グである. 光パスコンディショニングは, 光パスプロ セッサによって切り替えられた光パスを光パス・インタ フェース間で適切に光伝送するための伝送路調整・補償 技術である。この3つが揃うことで，ダイナミック光パ スネットワークはその物理レイヤーの機能が完成するこ

${ }^{\dagger}$ Cisco Visual Networking Index: Forecast and Methodology, 2008-2013 [Online]. Available: URL: http://www9.cisco.com/en/US/solutions/ collateral/ns341/ns525/ns537/ ns705/ns827/white_paper_c11-481360_ns827_Networking_Solutions_White_Paper.html 


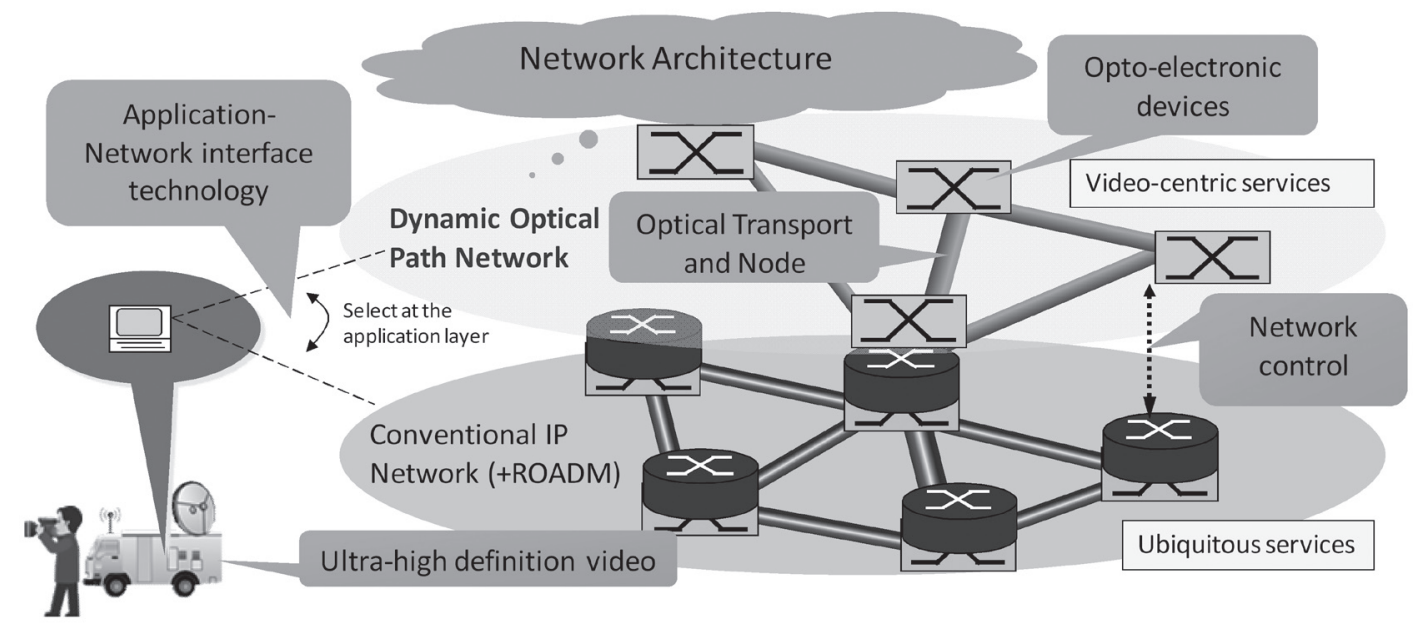

Fig. 3 Conceptual diagram of the DOPN co-installed with the conventional IP networks.

とになる。

以下は，産総研における活動例をそれぞれについて紹 介していく.

（1）光パス・インタフェース：集積光デバイスによっ て構成される時分割多重光ネットワークインタ フェースカード (OTDM-NIC) 技術

ダイナミック光パスネットワークの重要な利点に, そ こを通る光信号の変調フォーマットが自由であることが ある，ユーザは，それぞれの目的に応じてさまざまな帯 域や伝送方式を採用することができ，ネットワーク上で これらが混在することも可能である.

OTDM伝送は, 超短パルスを用いて時間軸上で光信号 を多重分離する技術であり，電子デバイス速度以上の速 度で伝送することが可能であり，次世代伝送技術として 期待されてきた ${ }^{8)}$. ところが, 最近のデジタル信号処理 技術の進展によってデジタルコヒーレント技術が実用化 され，今後の光伝送技術の主流になりつつある ${ }^{9)}$. しか し，さらにその先の技術を見据えたとき，同技術ではデ ジタル信号処理が性能的にもエネルギー的にもボトル ネックになることが懸念される. その点, OTDMは伝送 速度が電子デバイスによって制限されないために, 比較 的低電力で電子デバイスを超えて高速化できる点で有望 である。

ただし，OTDM伝送技術には依然として3つの大きな 技術的課題がある。ひとつは, 超短パルスを発生し非線 形光学現象を用いて超高速光ゲート処理を行うため, サ イズが大きなモード同期レーザーや非線形ファイバ, EDFAなどを用いるために，集積化が困難であること．

2つ目は, OTDMの受信器におけるクロック抽出および 分離時のチャンネル識別が困難であったこと。そして, 3つ目は，超短パルスが伝送路の高次分散の影響を受け その補償が困難であったことである。

産総研では，これら3つの課題に対して革新的な技術 を提案し研究開発を進めている。まず1つ目の課題であ る集積化について, 産総研は近年発見されたサブバンド 間遷移 (ISBT) 量子井戸導波路中の相互位相変調効果 ${ }^{10,11)}$ を用いた超高速光ゲートを開発した ${ }^{12)}$ 。我々は, ISBT
素子と主要部品に集積可能な半導体光増幅器 (SOA), ク ロック光パルス光源にモノリシック半導体モード同期 レーザー(MLLD), OTDM前の $43 \mathrm{G}$ 光信号光源に電界吸 収型変調器内蔵型半導体レーザ(EML)を用いた $172 \mathrm{Gbit} /$ sOTDM伝送に成功した ${ }^{13)}$ 。その際の実験構成，信号波 形, ビットエラー特性をFig. 4に示す.

ビットエラー特性は, 単位時間当たりのビットエラー 数 (BER)の受信器への光パワー依存性を調べたもので, 信号自体のSNが劣化すると同じ入力パワーでも悪いエ ラー特性となる. Fig. 4右下の曲線を比較するとOTDM したことで大きなSN劣化が見られないことが分かる. 基本的な伝送特性は, ISBTの動作効率を改善すること でさらに改善されることが予想される。

2つ目の技術課題である, クロック抽出とチャネル識 別については，4つの43 G OTDMトリビュータリ光信号 毎に時間的な隙間を空けることにより，常に172 Gbit/s 信号に43 GHzの信号トーンを設け， かつ，その信号 トーンの位相がOTDMチャンネルに対して常に固定とな るように工夫した ${ }^{14)}$. その結果, 光スイッチで2つの $172 \mathrm{Gbit} / \mathrm{s}$ OTDM信号を切り替えても, 受信側で高速か つ安定的にクロック抽出を実現し, さらに常に所望の チャンネルを抜き出すことに成功した，その際，光ス イッチで送信器を切り替えても $10 \mu$ 秒には切り替え後の OTDM信号からクロック抽出が完了し位相ロックがかか ることが確認された。チャンネル識別が毎回安定的に動 作することについては，実際に映像信号を通し，所望の 映像が伝送されることで確認をした

3つ目の課題について, 産総研では独自の光パラメト リック過程を用いる可変分散補償(P-TDC) を提案し ${ }^{16)}$, ピコ秒パルスによる $172 \mathrm{Gbit} / \mathrm{s}$ OTDM伝送の可変分散補 償を行った ${ }^{17)}$ 。さらに，4次分散補償まで考慮したフェ ムト秒パルスの可変分散補償に成功している ${ }^{18)}$. P-TDC に関する詳細は, (3) 光パス・コンディショニングで述 ベる.

このように，OTDM技術は，光送受信部が集積化によ りバタフライパッケージ程度の大きさになり, 既存の電 子デバイスによる安定したクロック抽出・チャネル識別 が適用され，伝送路の高次分散も自律的に補償され安定 


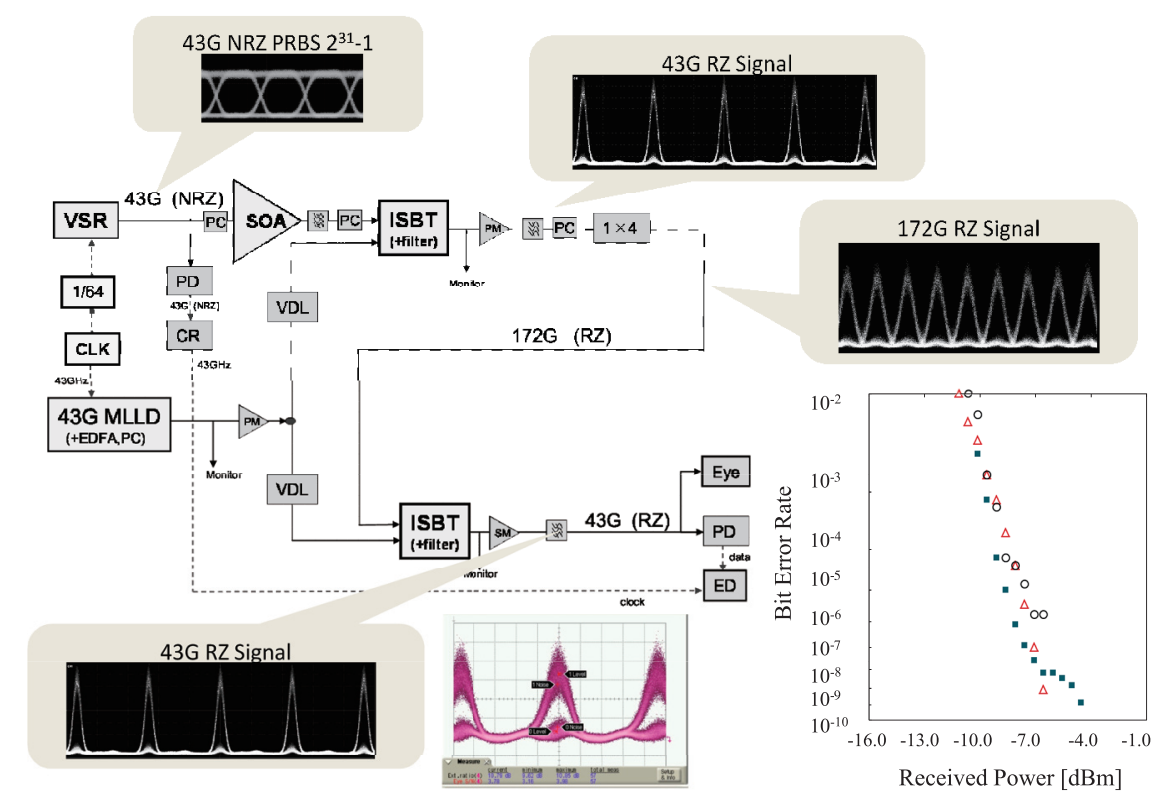

Fig. 4 Experimental setup and results (eye pattern and BER characteristics) of $172 \mathrm{Gbit} / \mathrm{s}$ OTDM transmission. In the BER curve, triangles are for the $43 \mathrm{Gbit} / \mathrm{s}$ NRZ Back-toback scheme, solid squares are for $43 \mathrm{Gbit} / \mathrm{s}$ RZ, open circles are for $172 \mathrm{Gbit} / \mathrm{s}$ OTDM. VSR: very short reach transceiver using EML for transmitter; CLK: clock; PD: photodiode; CR: clock recovery; PC: polarization controller; PM: polarization maintaining EDFA; Eye: eye pattern measurement; ED: error detector.

な伝送が可能となれば実用化の道も開ける。

(2) 光パス・プロセッサ：シリコンフォトニクスによ る光マトリックス・スイッチ

現在までのところ，ネットワークにおいて本格的に用 いられた光スイッチには, リコンフィギュラブル光アッ ド・ドロップ・マルチプレクシング(ROADM)用の波長 選択スイッチ(WSS)がある。言い換えれば，それ以外 は，ほどんどネットワークに用いられた事例がないとい える。その要因として, 光スイッチは, 大規模なポート 数の実現が難しい, コストや大きさに問題がある, など が挙げられる。

産総研では，シリコンフォトニクスによる光マトリッ クス・スイッチの開発を推進している。シリコンフォト ニクスは, 光の閉じ込めが強いため従来の石英平面光導 波路に比べて飛躍的に小さくでき, その結果, ポート数 の増大が可能である。実際に, $8 \times 8$ マトリックスス イッチにアレイド・ウェーブガイド・グレーティング (AWG)を集積したシリコンフォトニクススイッチが, $3 \mathrm{~mm} \times 12 \mathrm{~mm}$ の大きさで実現されている年，さらに， シリコンフォトニクスはCMOSとの親和性も良く，光ス イッチ上にその制御回路を集積化することも可能であ り，その点でも大規模化に有利である.

産総研では, シリコンフォトニクスで光スイッチを実 現する方法として，マッハツェンダー干渉計にヒータも しくは電極を形成しシリコンの熱光学効果もしくは電流 注入によるプラズマ効果を利用するものを検討してい る. いずれも消費電力は非常に小さい. 熱光学効果で は, ポート当たり $40 \mathrm{~mW}$ 程度 ${ }^{20)}$, プラズマ効果では, $1.5 \mathrm{~mW}$ 程度 ${ }^{21)}$ と, 光スイッチと併用する光増幅器の消
費電力に比べ無視できる程度である。さらに，スイッチ 速度も，熱光学効果で山秒，プラズマ効果でn秒台が実 現可能であり，MEMS，液晶，石英PLCなどを用いる既 存技術に比して桁違いに優れた特性を示している

この様にシリコンフォトニクスは，その材料の物理特 性が大規模な光スイッチに適しているが，屈折率が石英 に比べて大きく閉じ込めが強い分, 導波路構造の要求精 度も厳しく十分な性能を実現するには本格的な製造技術 の高精度化が必要である。

(3) 光パス・コンディショニング：パラメトリック過 程を用いる光ノード機能

光パス・コンディショニングは，光パスがダイナミッ クに切り替わる状況において，常に光パス上を流れる光 信号が適切に送信先に伝送されるように伝送品質を維持 する技術である。具体的には，(1)SNRの維持，（2)分散 補償，（3）切り替えに伴うトランジェント対策，(4)これ らを制御・監視するモニ夕技術などが重要である。これ ら項目は，光通信全般においても重要な課題としてさま ざまな取り組みが行われてきたが，実用化した実際の光 通信においては，ダイナミックかつ不特定に光伝送条件 が変わるような状況はほとんど想定されていない。従っ て，ダイナミック光パスネットワーク実現には，従来の 光通信技術では未だ達成されていない「ダイナミック」と いう大きな課題を克服する必要がある.

産総研では，ダイナミック光パスネットワークで特に 重要と思われる特長として，光信号フォーマットに無依 存 (位相・多值変調信号にも適用可能)であること, そし て，信号の動作波長・帯域に無依存であることの2点を 考慮し，光パラメトリック過程を活用する光信号処理技 
術の研究開発を進めている ${ }^{22}$.

光ファイバを用いるパラメトリック過程は, 超高速, 広帯域, 低雑音, 高ダイナミックレンジ(線形性), 位相 情報の保持, 波長可変性, 高信頼, 潜在的にコンパクト かつ低コスト性がある，という比類ない特長を有するた め, 光パス・コンディショニング機能を実現する物理現 象として非常に魅力的である.

光パラメトリック過程を用いて実現可能な光ノード機 能としては，広帯域・任意波長変換器，高速波長スイッ 于, 高速 - 広帯域可変分散補償器 (P-TDC), 広帯域可変 光遅延装置, 光増幅器, 光信号再生器, 全光変調フォー マット変換器, 全光多重分離器, OTDM光ゲートなどが あり，全光信号処理に期待される光パス・コンデイショ ニング機能としてはほぼすべての種類に，単に対応でき
るだけでなく，フレックスグリッドにも対応可能な高い 柔軟性を兼ね備えている。

産総研の独自技術であるP-TDCの比類ない広帯域性を 活用する一例として，172 Gbit/s OTDM伝送の結果を Fig. 5に示す ${ }^{17)}$. OTDM伝送のような伝送路の高次分散 が問題になる領域には不可欠な技術である。同様に， WDM信号を一括可変分散補償した結果をFig. 6に示す.

P-TDCの比類ない特長は, このような広帯域性たけで なく，可変分散の応答速度にもある，従来の可変分散補 償技術は，熱や機械的な原理で分散を可変にしていたた め，分散值を変化するのにm秒から秒オーダーの応答時 間となっていた。これに対して，P-TDCは，分散值を変 化させるのに，パラメトリック過程におけるポンプ波長 を変化させればよいため, 原理的にはn秒オーダーの高

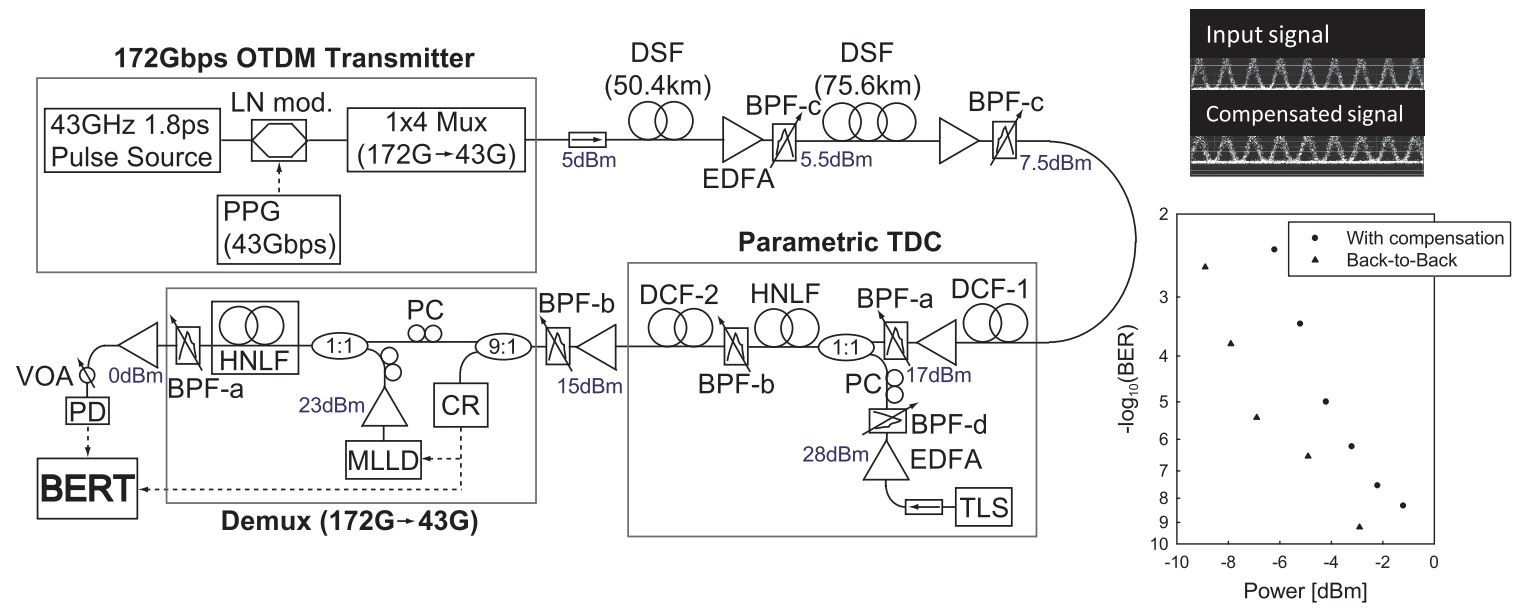

Fig. 5 Experimental setup for $172 \mathrm{Gbit} / \mathrm{s}$ transmissions using P-TDC (left) and the results (right). Upper right: $172 \mathrm{Gbit} / \mathrm{s}$ eye patterns for the transmitter (up) and after P-TDC(down); Lower right: BER characteristics; LN mod: Lithium Niobate Modulator; HNLF: highly nonlinear fiber for parametric process; DSF: dispersion shifted fiber; DCF: dispersion compensating fiber; BPF: bandpass filter; VOA: variable optical attenuator; BERT: BER tester.
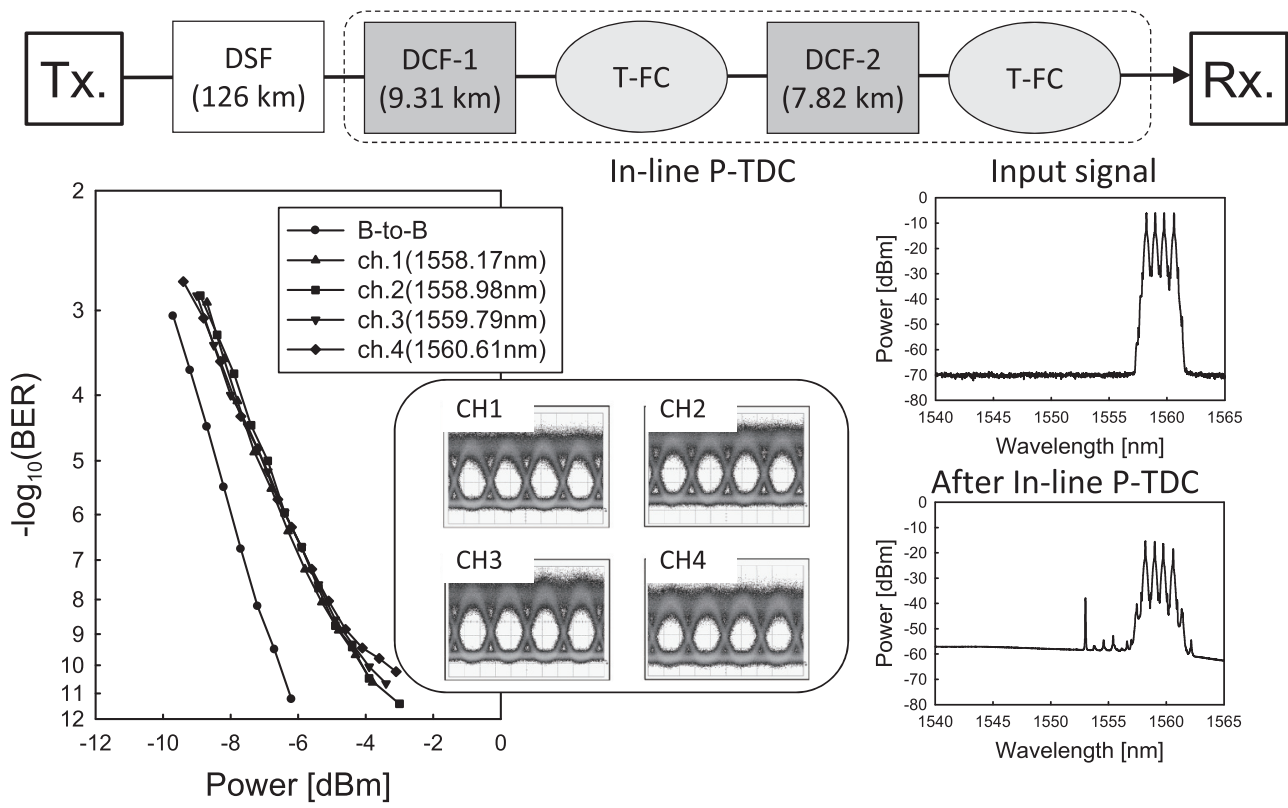

Fig. 6 Simultaneous dispersion compensation of WDM signals using P-TDC. T-FC stands for tunable frequency converter. 


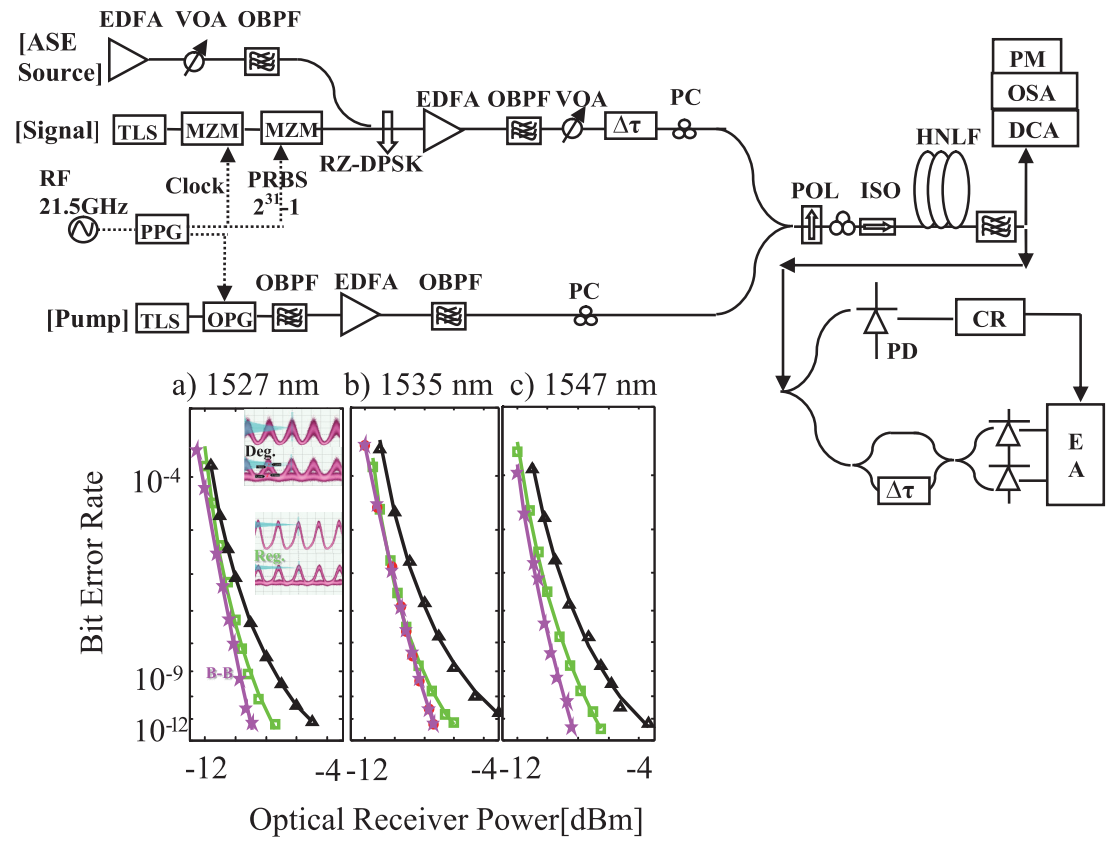

Fig. 7 Experimental setup for T-OPR (upper). And BER charactericstics (lower) where denotes B-to-B; $\triangle$ : degraded signals; $\square$ : signals after T-OPR.

速応答性が可能である，我々は，実際にP-TDCのポンプ 波長の応答速度が $\mu$ 秒オーダーで動作することを確認 し，分散補償としても良好なBER特性を得た23.

光パス・コンディショニングのもう1つの重要な機能 として, SNRの維持, すなわち, 光信号再生がある. 光 信号再生では，いわゆるマミシェブ型フィル夕を用いた $10^{6} \mathrm{~km}$ 伝送が有名である ${ }^{24}$ が，これは自己位相変調に基 づいているために，位相変調信号には適用できない，そ こで, 位相変調信号に対してパラメトリック効果に基づ いた光信号再生が研究されている 信号の位相雑音の再生技術として, パラメトリック効果 を用いる位相感応型増幅過程を活用する方法も提案され ている26,27).

このように，パラメトリック効果を用いることで，さ まざまな機能を実現できることが分かる，ところが，実 際にこれらの機能を光ネットワークに盛り込む際, 機能 の数だけデバイスが必要ならばその分デバイスを多用し なければならなくなる。そこで, 産総研では, 極力複数 の機能を1つないし集約された構成で実現できる検討を 進めている, その一例として, 波長可変型光信号再生器 (T-OPR)の研究に取り組んでいる。 これは, 従来のパラ メトリック光信号再生と異なり, 再生される入力信号の アイドラ光を出力として使㧍うという提案である.この とき，パラメトリック過程のポンプ波長を変化させても 均一な信号再生効果が得られるように設計できれば，可 変波長変換と光信号再生機能の $2 つ を$ 同時にひとつの構 成で実現できることになる。すでに我々は低スロープ型 HNLFを用いてこれを実証した。その際の実験系とビッ トエラーレートの改善効果をFig. 7に示す ${ }^{28)}$. 図より, T-OPRによって, 伝送ペナルティーが改善されたことが 分かる.

パラメトリック効果を用いることで，光信号再生が位
相変調信号にも適用できることになるが，完全な光信号 再生を実現するために振幅再生だけでなく，位相再生や タイミング再生を盛り込もうとすると, 光信号再生動作 が，光信号のビットレートや変調フォーマットに依存す ることになり，ダイナミック光パスネットワークの利点 である光信号変調フォーマット無依存性が損なわれてし まう。そこで，今後は，簡易な遠隔操作で構成が切り替 わり複数の変調フォーマットやビットレートに対応でき る工夫が望まれる。

さらに産総研は，今後は，上記P-TDCとT-OPRを組み 合わせることを検討する予定である。これにより，分散 補償・任意波長変換・光信号再生の $3 つ の$ 機能がひとつ のデバイスに構成されることになり，ダイナミック光パ スネットワークに必要な光パスコンデイショニングの主 要機能がひとつのサブシステムに収容されることになる。

\section{4. まとめ}

将来にわたりネットワークの持続的発展を維持し, ト ラフィックを増大させ続けるためには，光スイッチを活 用するダイナミック光パスネットワーク技術の創出が必 要であり，その要素技術について，産総研の取り組みを 中心に紹介した。

\section{謝 辞}

本研究成果の一部は, 独立行政法人新エネルギー・産 業技術総合開発機構(NEDO)の委託事業「次世代高効率 ネットワークデバイス技術開発」，抢よび，文部科学省 イノベーションシステム整備事業によるものである. 


\section{参考文献}

1) R.-J. Essiambre, G. Kramer, P. J. Winzer, G. J. Foschini, and B. Goebel: J. Lightwave Technol. 28 (2010) 662.

2) D. Qian, M. Huang, E. Ip, Y. Huang, Y. Shao, J. Hu, and T. Wang: in Proc. OFC, Los Angeles, 2011, Paper PDPB5.

3) S. Namiki, T. Kurosu, K. Tanizawa, J. Kurumida, T. Hasama, H. Ishikawa, T. Nakatogawa, M. Nakamura, and K. Oyamada: IEEE J. Sel. Top. Quantum Electron. 17 (2011) 446.

4) R. Tucker: the Opt. Fiber Commun. Conf. Expo. Nat. Fiber Opt. Eng. Conf. [CD-ROM] (Optical Soc. Amer., Washington, DC, 2008) OMG1.

5) 石川浩, 並木周, 工藤知宏：産総研Today 10 (2010) 4. もしくはhttp://www.aist-victories.org/を参照のこと

6) K. Ishii, J. Kurumida, T. Hasama, H. Ishikawa, and S. Namiki: submitted to Telecommunication Systems J.

7) S. Shioda and S. Namiki: Photon. Netw. Commun. 19 (2010) 32.

8) H. G. Weber and M. Nakazawa (Eds.): Ultrahigh-Speed Optical Transmission Technology (New York: Springer, 2007).

9) S. Tsukamoto, K. Katoh, and K. Kikuchi: IEEE Photon. Technol. Lett. 18 (2006) 1016.

10) K. S. Abedin, G.-W. Lu, T. Miyazaki, R. Akimoto, and H. Ishikawa: Opt. Express 16 (2008) 9684.

11) H. Tsuchida, T. Simoyama, H. Ishikawa, T. Mozume, M. Nagase, and J. Kasai: Opt. Lett. 32 (2007) 751.

12) R. Akimoto, S. Gozu, T. Mozume, and H. Ishikawa: Conference on Lasers and Electro-Optics (2011) paper CTuW2.

13) T. Kurosu, S. Namiki, R. Akimoto, H. Kuwatsuka, S. Sekiguchi, N. Yasuoka, K. Morito, T. Hasama, and H. Ishikawa: IEEE Photon. Technol. Lett. 22 (2010) 1416.

14）黑須隆行：特願2012-016123.

15) T. Kurosu, K. Tanizawa, S. Namiki, R. Akimoto, H. Kuwatsuka, T. Hasama, H. Ishikawa, T. Nakatogawa, K. Oyamada, Y. Tanaka, S.
Ide, H. Onaka, and T. Asami: OFC NFOEC 2012, PDP5C.10.

16) S. Namiki: J. Lightw. Technol. 26 (2008) 28.

17) K. Tanizawa, T. Kurosu, and S. Namiki: Opt. Express 18 (2010) 10594.

18) T. Kurosu, K. Tanizawa, S. Petit, and S. Namiki: Opt. Express 19 (2011) 15549

19) T. Hino, M. Sakauchi, J. Kurumida, S. Namiki, S. Takahashi, S. Nakamura, and A. Tajima: The 16th Opto-Electronics and Communications Conference (OECC), 2011.

20) Y. Shoji, K. Kintaka, S. Suda, H. Kawashima, T. Hasama, and H. Ishikawa: Opt. Express 18 (2010) 9071

21) S. Sekiguchi, T. Kurahashi, K. Kawaguchi, and K. Morito: IEEE Photonics Society 23rd Annual Meeting, 2010, p. WW3.

22) S. Namiki, T. Kurosu, K. Tanizawa, S. Petit, M. Gao, and J. Kurumida: IEEE J. Sel. Top. Quantum Electron. 18 (2012) 717.

23) K. Tanizawa, J. Kurumida, H. Ishida, Y. Oikawa, N. Shiga, M. Takahashi, T. Yagi, and S. Namiki: Opt. Lett. 35 (2010) 3039.

24) G. Raybon, Y. Su, J. Leuthold, R.-J. Essiambre, T. Her, C. Joergensen, P. Steinvurzel, and K. D. K. Feder: the Optical Fiber Communication Conf. and Exhibit, Anaheim, 2002, Proc. PostDeadline Papers, Paper FD10.

25) M. Matsumoto and T. Kamio: IEEE J. Sel. Top. Quantum Electron. 14 (2008) 610.

26) K. Croussore and G. Li: IEEE J. Sel. Topics Quantum Electron. 14 (2008) 648

27) F. Parmigiani, R. Slavic, J. Kakande, C. Lundstr, M. Sj, P. Andrekson, R. Weerasuriya, S. Sygletos, A. D. Ellis, L. Grielsen, D. Jakobsen, S. Herstr, R. Phelan, J. O Gorman, A. Bogris, D. Syvridis, S. Dasgupta, P. Petropoulos, and D. J. Richardson: Optical Fiber Communication Conference, OSA Technical Digest (CD) (Optical Society of America, 2010), paper PDPC3.

28) M. Gao, J. Kurumida, and S. Namiki: Opt. Express 19 (2011) 23258

\section{レーザーワード}

ダイナミック光パスネットワーク (dynamic optical path network: DOPN)

ユーザやアプリケーションからのリクエストに直接応 じて, 光スイッチをダイナミックに切り替えることで ネットワーク・サービスを行うことを特徴とする高速光 回線交換網。従来のIPネットワークでは, パケット状 データをIPルータで処理するため, データプレーンと制 御プレーンが共通であり自由度が高い反面, 超高精細映
像のような巨大容量データの転送には効率が悪いという 問題があった，光スイッチの消費エネルギーは，IPルー 夕と異なりデー夕容量に対してほとんど一定であるため 将来の持続発展的ネットワーク技術として期待されてい る.

(並木 周) 